\title{
Alveolar Hemorrhage and Acute Respiratory Distress Syndrome Associated with Pulmonary Cement Following Percutaneous Vertebroplasty with Polymethylmethacrylate
}

\author{
Basheer Al-Sanouri ${ }^{1}$, Ibrahim Al-Sanouri ${ }^{2}$ \\ ${ }^{1}$ College of Science, Michigan State University, Lansing, USA \\ ${ }^{2}$ Department of Pulmonary and Critical Care, Gunderson Health System, La Crosse, USA \\ Email: b.sanouri@gmail.com, isanouri@hotmail.com
}

How to cite this paper: Al-Sanouri, B. and Al-Sanouri, I. (2016) Alveolar Hemorrhage and Acute Respiratory Distress Syndrome Associated with Pulmonary Cement Following Percutaneous Vertebroplasty with Polymethylmethacrylate. Case Reports in Clinical Medicine, 5, 419-425.

http://dx.doi.org/10.4236/crcm.2016.511058

Received: October 7, 2016

Accepted: October 31, 2016

Published: November 3, 2016

Copyright $\odot 2016$ by authors and

Scientific Research Publishing Inc.

This work is licensed under the Creative

Commons Attribution International

License (CC BY 4.0).

http://creativecommons.org/licenses/by/4.0/

\begin{abstract}
We report a rare complication of diffuse alveolar hemorrhage and respiratory failure following percutaneous vertebroplasty in a patient who has evidence of cement leakage. Cement injection was done two days prior to presentation and covered 2 vertebral levels for osteoporosis induced fractures.
\end{abstract}

\section{Keywords}

ARDS: Adult Respiratory Distress Syndrome, DAH: Diffuse Alveolar Hemorrhage, ICU: Intensive Care Unit, PMMA: Polymethylmethacrylate

\section{Introduction}

Percutaneous cementoplasty (also known as vertebral packing or vertebroplasty) with acrylic cement (polymethylmethacrylate [PMMA]) is a procedure aimed at preventing vertebral body collapse and pain [1] [2]. The first percutaneous cementoplasty was performed by Deramond et al., who originated the method in 1984. Since that time, the interest in percutaneous cementoplasty has grown and many technical improvements have been made [3].

The principle of the procedure is to provide analgesic and consolidation effects to the diseased bone and to prevent further collapse and pain. The ultimate goal is to improve patient functional status [4] [5].

The procedure is simply done under CT images by inserting a small tube inside the damaged vertebrae after local anesthetics. A toothpaste like material, PMMA, is then 
injected slowly with appropriate amount into the bone. When the material hardens, consolidation effects take place and the bone becomes stabilized. The patient usually experiences pain relief within 4 to 24 hours [6] [7] [8].

The indications for this procedure have been increasing; examples of such indications are: Symptomatic vertebral angioma, painful vertebral body tumors, Metastases and Myeloma, refractory severe painful osteoporosis with loss of height and/or with compression fractures of vertebral bodies.

The most common side effects are infection and hematoma at the site of injection [9]. However, if the needle is not properly placed in the vertebral body or the injected volume is too large, then cement leak into the vertebral plexus could take place [10]. Too rapid injections could also result in cement leak. This material is hazardous in term of causing local injury. Once leaked, it may travel through the circulation and could lead to remote organ damages.

Renal Vein cement thrombosis and pulmonary embolism have been reported as rare and sometimes fatal complications. Valvular injury and even right ventricular rupture from hard cement has been reported. Cases of ARDS due to cement pulmonary embolism have been described from different centers around the word [11] [12] [13] [14].

Our main objective in reporting this case is to alert physicians and patients about another life threatening complication associated with a procedure which is considered once to be simple, safe, and effective.

\section{Case Report}

A 59-year-old female came to the emergency department complaining of shortness of breath, fatigue, and low grade fever. Two days prior to presentation she underwent Vertebroplasty procedure for T-12, L-1 Vertebral body compression fractures.

Vertebroplasty was done under local anesthesia using Acrylic Cement. The procedure was prolonged but uneventful. Upon presentation the patient denied any cough or sputum production. She did have chills and body aches. On admission, Temperature was $100.1 \mathrm{~F}$. with Respiratory rate of 28 breaths per minute. On examination, she was found to have coarse breath sounds with normal cardiac vascular exam. The site of Vertebroplasty was intact and dry. Oxygen Saturation was $91 \%$ on 2 liter per Minute Nasal cannula. Chest x-ray upon admission was with no significant pathology (Figure 1).

Two days after admission; diffuse alveolar infiltrates developed (Figure 2). Patient was transferred to the Intensive Care Unit (ICU) and placed on mechanical ventilator support. Patient was treated as a case of adult respiratory distress syndrome (ARDS). Trans echocardiography was done and revealed no abnormalities.

Flexible Bronchoscope showed no bronchial lesions. Alveolar lavage with multiple consecutive aliquots of $50 \mathrm{ml}$ of Normal saline was performed. Bloodier returns were documented among lavage tubes. Microscopic exam shows 50\% Hemosidrinladened macrophages. Chest CT scan without contrast showed grains of Cement in the pulmonary parenchyma particularly in the left lower lobe (Figure 3 ). In addition, there was a two grams drop in the hemoglobin (from 9 to $7 \mathrm{~g} / \mathrm{dl}$ ). The diagnosis of diffuse alveolar 


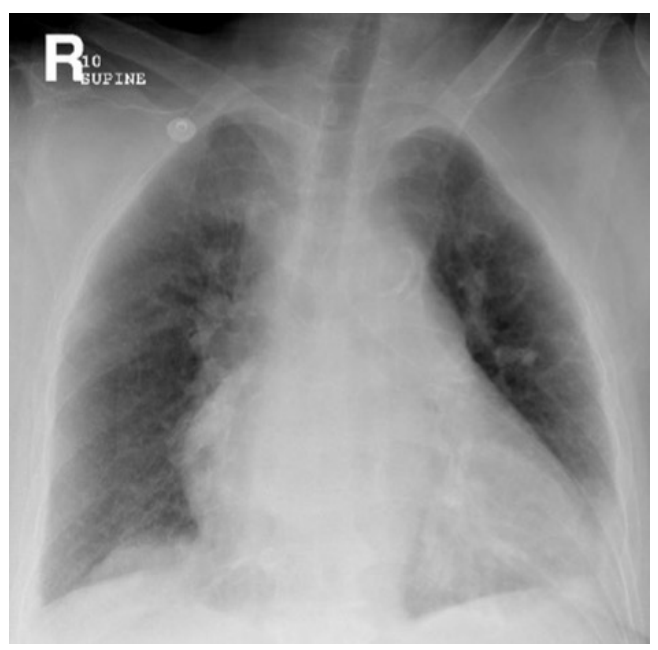

Figure 1. Portable chest x-ray at presentation. Clear lungs with mild left sided pleural effusion.

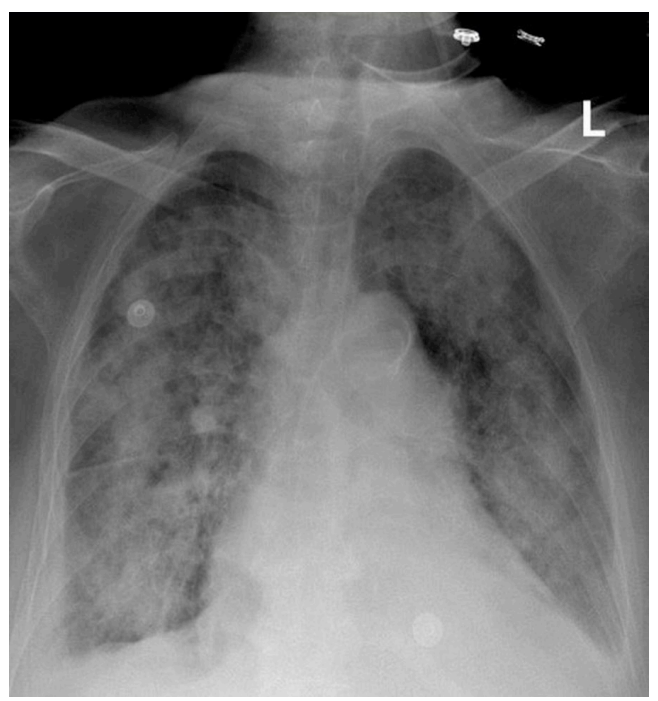

Figure 2. Portable chest x-ray two days after admission. Diffuse bilateral alveolar infiltrates.

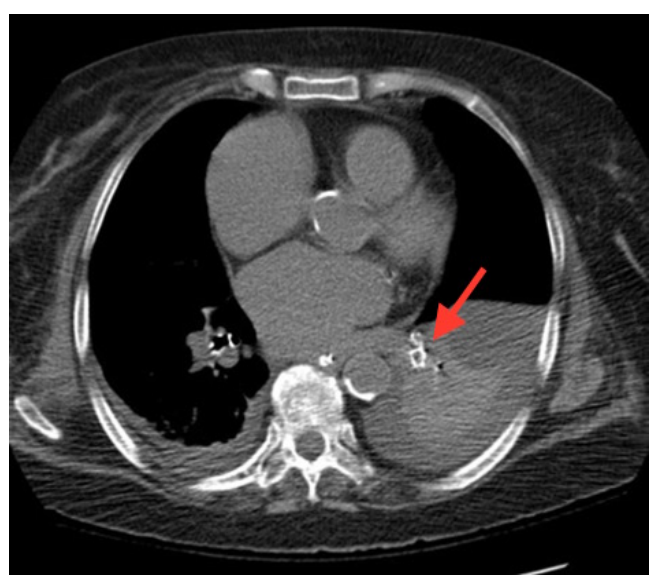

Figure 3. CT chest without contrast. Grains of Cement in the pulmonary parenchyma at the left lower lobe. See red arrow. 
hemorrhage (DAH) was confirmed. Supportive treatment was followed. MRI of the spine showed cement leak through the Para vertebral muscles with no signs of abscess (Figure 4). On day 10, patient was successfully weaned off the ventilator (Figure 5). She was then transferred to the general medical floor where she spent one more week. Her respiratory status continued to improve and she was eventually released home on 1 liter per minute oxygen therapy.

\section{Discussion}

Local and systemic Cement leak is operator dependent. Improper Needle position, high injected volume, and fast injection could lead to material Leak into the vertebral venous

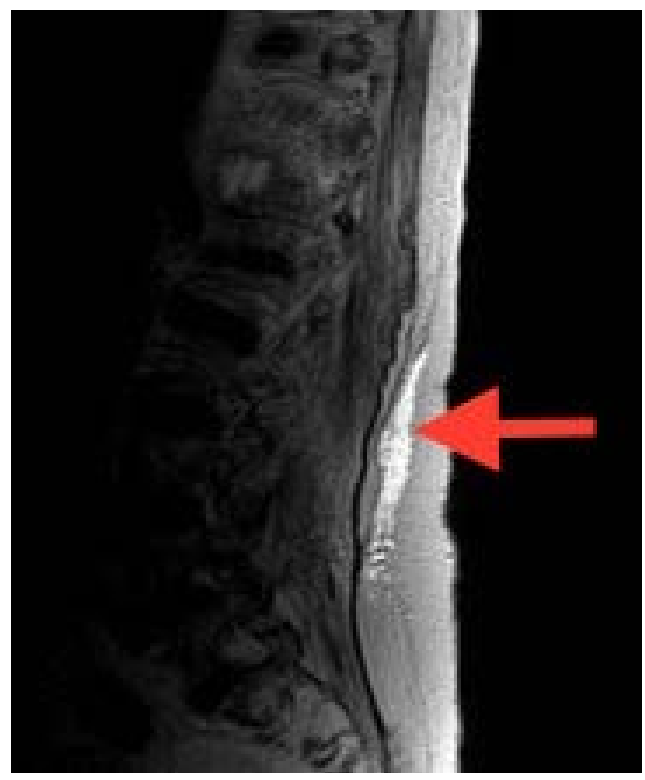

Figure 4. MRI of the thoracic and lumbar spine. Cement leak through the Para vertebral muscles. See red arrow.

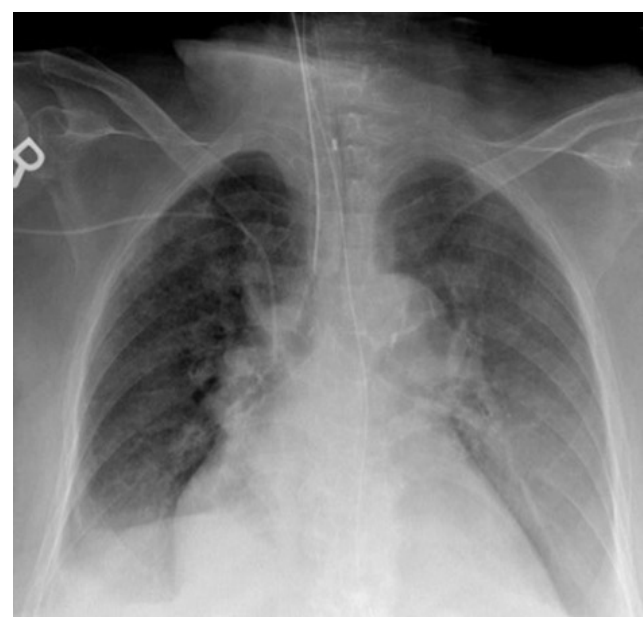

Figure 5. Chest X-ray just before weaning off the ventilator. Clearing previously noted alveolar infiltrates with trachealtube in place. 
plexus and therefore into the circulation. The hard material could cause local tissue damage, acute pulmonary embolism, and cardiac tissue damages.

Safety measures to reduce the risk of cement extravasation include high quality permanent radiological guidance enabling early detection of cement extravasation, careful selection of the bone penetration site in order to make a single vertebral needle path, and careful needle placement to avoid the risk of cortical breakthrough.

Some authors advocate Vertebral Venography to assure appropriate technique and to prevent such leak.

Acute Pulmonary embolism and ARDS have been described in the literature, and it has been associated with mortality [13]. In 2002, Jang et al. reported three cases of pulmonary embolism caused by polymethylmethacrylate (PMMA) after percutaneous vertebroplasty [14].

In 2006, Syed MI et al. reported a fatal case of fat embolism after vertebroplasty [15]. Surprisingly, there was no evidence of cement leak in that particular case. Cardiac perforation is another rare complication of vertebroplasty, with only one fatal case report in the literature [16]. Cerebral embolus has also been reported to occur and is attributed to fat emboli from raised intramedullary pressure during cementation [17].

DAH is a newly described complication that was diagnosed in this case with evidence of cement in the lung.

Although not completely explained, DAH could be caused by pulmonary capillaries rupture under the effect of hard material. Allergic reaction to the cement with cytokine release might be also another explanation. Meticulous and careful technique during material injection would prevent cement leak.

In general DAH by itself does not necessary carry a grim prognosis. It does, however, cause respiratory failure that may require mechanical ventilation support. There is no specific treatment for DAH caused by cement leak. The management is mainly supportive. During the ICU stay, hospital and ventilator acquired infections are essential to prevent.

In the Investigational Vertebroplasty Safety and Efficacy Trial (INVEST), Kallmes et al. report that pain and disability outcomes at 1 month in a group of patients who underwent vertebroplasty were similar to those in a control group that underwent a sham procedure [18]. In other trial, Buchbinder et al. measured pain, quality of life, and functional status at 1 week and at 1,3 , and 6 months after sham and active vertebroplasty and found there were no significant between-group differences at any time [19].

In the light of increasingly reported life threatening adverse effects and limited benefits, we advocate that patients should be fully educated about the risks and benefits of this frequently performed procedure [20] [21].

\section{Conclusion}

Percutaneous vertebroplasty, among various other options, has become a mainstay in the management of osteoporotic and malignant vertebral fractures. Vertebroplasty is not a procedure without complications. Some of these complications are fatal. The 
purpose of this report is to describe another life threatening complication arising from that procedure. In this case the patient developed DAH and ARDS and required mechanical ventilator support two days after the cement injection.

\section{References}

[1] Hulme, P.A., Krebs, J., Ferguson, S.J. and Berlemann, U. (2006) Vertebroplasty and Kyphoplasty: A Systematic Review of 69 Clinical Studies. Spine, 31, 1983-2001.

http://dx.doi.org/10.1097/01.brs.0000229254.89952.6b

[2] Peh, W.C., Munk, P.L., Rashid, F. and Gilula, L.A. (2008) Percutaneous Vertebral Augmentation: Vertebroplasty, Kyphoplasty and Skyphoplasty. Radiologic Clinics, 46, 611-635. http://dx.doi.org/10.1016/j.rcl.2008.05.005

[3] Galibert, P., Deramond, H., Rosat, P. and Le Gars, D. (1987) Preliminary Note on the Treatment of Vertebral Angioma by Percutaneous Acrylic Vertebroplasty. Neurochirurgie, 33, 166-168.

[4] Alvarez, L., Alcaraz, M., Perez-Higueras, A., et al. (2006) Percutaneous Vertebroplasty: Functional Improvement in Patients with Osteoporotic Compression Fractures. Spine, 31, 1113-1118. http://dx.doi.org/10.1097/01.brs.0000216487.97965.38

[5] Ettinger, B., Black, D.M., Nevitt, M.C., et al. (1992) Contribution of Vertebral Deformities to Chronic Back Pain and Disability. Journal of Bone and Mineral Research, 7, 449-456.

http://dx.doi.org/10.1002/jbmr.5650070413

[6] Buchbinder, R., Osborne, R.H., Ebeling, P.R. and Wark, J.D. (2009) A Randomized Trial of Vertebroplasty for Painful Osteoporotic Vertebral Fractures. The New England Journal of Medicine, 361, 557-568.

[7] McGraw, J.K., Lippert, J.A., Minkus, K.D., Rami, P.M., Davis, T.M. and Budzik, R.F. (2002) Prospective Evaluation of Pain Relief in 100 Patients Undergoing Percutaneous Vertebroplasty: Results and Follow-Up. Journal of Vascular and Interventional Radiology, 13, 883886. http://dx.doi.org/10.1016/S1051-0443(07)61770-9

[8] Trout, A.T., Kallmes, D.F., Gray, L.A., et al. (2005) Evaluation of Vertebroplasty with a Validated Outcome Measure: The Roland-Morris Disability Questionnaire. American Journal of Neuroradiology, 26, 2652-2657.

[9] Layton, K.F., et al. (2007) Vertebroplasty, First 1000 Levels of a Single Center: Evaluation of the Outcomes and Complications. American Journal of Neuroradiology, 28, 683-689.

[10] McGraw, J.K., Cardella, J., Barr, J.D., et al. (2003) Society of Interventional Radiology Quality Improvement Guidelines for Percutaneous Vertebroplasty. Journal of Vascular and Interventional Radiology, 14, 827-831. http://dx.doi.org/10.1016/S1051-0443(07)60242-5

[11] Childers Jr., J.C. (2003) Cardiovascular Collapse and Death during Vertebroplasty. Radiology, 228, 902-903. http://dx.doi.org/10.1148/radiol.2283030235

[12] Mathis, J.M. and Wong, W. (2003) Percutaneous Vertebroplasty: Technical Considerations. Journal of Vascular and Interventional Radiology, 14, 953-960. http://dx.doi.org/10.1097/01.RVI.0000083255.29749.A8

[13] Yoo, K.Y., Jeong, S.W., Yoon, W. and Lee, J. (2004) Acute Respiratory Distress Syndrome Associated with Cement Pulmonary Embolism Following Percutanous Vertebroplasty with Polymethylmethacrylate. Spine, 29, E294-E297.

[14] Jang, J.S., Lee, S.H. and Jung, S.K. (2002) Pulmonary Embolism of Polymethylmethacrylate after Percutaneous Vertebroplasty: A Report of Three Cases. Spine (Phila Pa 1976), 27, E416-E418. 
[15] Syed, M.I., Jan, S., Patel, N.A., Shaikh, A., Marsh, R.A. and Stewart, R.V. (2006) Fatal Fat Embolism after Vertebroplasty: Identification of the High-Risk Patient. American Journal of Neuroradiology, 27, 343-345.

[16] Kim, S.Y., Seo, J.B., Do, K.H., Lee, J.S., Song, K.S. and Lim, T.H. (2005) Cardiac Perforation Caused by Acrylic Cement: A Rare Complication of Percutaneous Vertebroplasty. American Journal of Roentgenology, 185, 1245-1247.

[17] Edmonds, C.R., Barbut, D., Hager, D. and Sharrock, N.E. (2000) Intraoperative Cerebral Arterial Embolization during Total Hip Arthroplasty. Anesthesiology, 93, 315-318. http://dx.doi.org/10.1097/00000542-200008000-00006

[18] Kallmes, D.F., Comstock, B.A., Heagerty, P.J., et al. (2009) A Randomized Trial Of Vertebroplasty for Osteoporotic Spinal Fractures. The New England Journal of Medicine, 361, 569-579. http://dx.doi.org/10.1056/NEJMoa0900563

[19] Buchbinder, R., Osborne, R.H., Ebeling, P.R., et al. (2009) A Randomized Trial of Vertebroplasty for Painful Osteoporotic Vertebral Fractures. The New England Journal of Medicine, 361, 557-568. http://dx.doi.org/10.1056/NEJMoa0900429

[20] Clark, W., Lyon, S. and Burnes, J. (2009) Trials of Vertebroplasty for Vertebral Fractures. The New England Journal of Medicine, 361, 2097-2100.

[21] Weinstein, J.N. (2005) Partnership: Doctor and Patient: Advocacy for Informed Choice vs. Informed Consent. Spine, 30, 269-272.

http://dx.doi.org/10.1097/01.brs.0000155479.88200.32

\section{Submit or recommend next manuscript to SCIRP and we will provide best service for you:}

Accepting pre-submission inquiries through Email, Facebook, LinkedIn, Twitter, etc.

A wide selection of journals (inclusive of 9 subjects, more than 200 journals)

Providing 24-hour high-quality service

User-friendly online submission system

Fair and swift peer-review system

Efficient typesetting and proofreading procedure

Display of the result of downloads and visits, as well as the number of cited articles

Maximum dissemination of your research work

Submit your manuscript at: http://papersubmission.scirp.org/

Or contact crcm@scirp.org 